\section{Australian universities told to commercialize}

A new Australian government policy on university research grants came under fire from academics and scientists last month for further tying funding to performance. The major policy statement "Knowledge and Innovation" outlines mechanisms for forcing universities to capitalize on their research—or lose money.

Federal education minister David Kemp was unrepentant that the thrust of the policy was to encourage universities to focus research in niche areas of excellence, despite criticism from scientists that basic research may suffer. It overhauls the higherdegree grants system to put fresh emphasis on each institution's ability to attract postgraduate students and research income, as well as on its publication record.

In a radical move, the government also earmarked money for research issues of benefit to rural Australia and will provide special assistance to regional universities. According to Kemp, this is part of the government's bid to stop the 'brain drain', in which talented researchers head overseas in search of better opportunities, job security and higher salaries. But the opposition seized on the bonus of $A \$ 16$ million (US $\$ 10.5$ million) for regional universities as a clear admission by the government that those institutions would have no hope of achieving the new performance-based requirements alone.

The Australian Academy of Science warned that by requiring such commercialization of discoveries, the government was heading down a path that threatened fundamental research. The Federation of Australian Scientific and Technological Societies also commented that far from encouraging diversity and excellence, the new policy might lead to an increasingly narrow focus for research: satisfying the demands of the industry of the day.

The paper, described by the minister as Australia's "most significant statement on university research in the last decade," was also criticized for failing to tackle the decline in government support for university funding. Fears were realized when the government released its three-year higher-education funding statement late on 24 December, showing that universities could count on receiving only half of their revenue from federal funds to 2002, with growing reliance on student fees and outside income.

Rada Rouse, Brisbane

\title{
University of Arizona misconduct investigation ruled improper
}

Supporters of Marguerite Kay, the first tenured professor to be fired from the University of Arizona (UA), are applauding a court ruling faulting the university for violating Kay's rights during a 1998 hearing on scientific misconduct charges. But, although the university has now been ordered to pay the Alzheimer researcher's legal fees, university officials contend that the ruling does not invalidate the verdict, and are refusing to act on a December 1999 request from a faculty committee calling for Kay's reinstatement.

Pima (Arizona) county superior court judge Stephen Villarreal found that the university should have allowed Kay to be represented by a lawyer at her misconduct hearing. But he sent the dispute back to the university, stating that the courts did not have the authority to rule on Kay's request for reinstatement.

In response to the schools failure to reinstate her, Kay filed a second suit last month, according to her attorney Don Awerkamp. But, she has also notified the state that she would settle her claims for $\$ 3$ million.

Kay was fired two years ago after an investigation into allegations that she "falsified, manipulated and otherwise misrepresented" data. In response, Kay filed suit, challenging the legality of both the investigation and the outcome (Nature 394, 817; 1998).

Since then, a group of her scientific colleagues have rallied in an attempt to exonerate and reinstate her. They say that the university created a case against her after she complained about the school's mismanagement of federal research funds. They describe Kay as a whistleblower and have posted a web page entitled "Witch hunt at the University of Arizona" (http://www.geocities.com/COL-

LEGEPARK/LAB/1222/).

The university casts the case differently. Officials there say that Kay's former employees charged that she mismanaged her lab and, as a result, published falsified research data. A faculty committee confirmed those charges, concluding that her work showed a "lack of scientific rigor and excessive carelessness," according to Thomas Cetas, professor of radiation oncology and a member of the investigatory panel.
One thing all parties agree on is that misconduct cases like this one are often divisive, expensive and highly emotional, while failing to get at the truth. Most of the time, investigations takes place at the university level, but some universities are better at it than others. "The institutions that have little or no experience do sometimes have problems," says Chris Pascal, acting director of the federal Office of Research Integrity, which monitors cases involving federally funded scientists. In the Kay case, the university stuck closely to the faculty review system it had established to handle such cases. But, when Kay sued, they learned that their process was vulnerable to a legal challenge.

Often, misconduct cases become complicated because of institutional politics, says Mark Frankel, director of the Scientific Freedom, Responsibility and Law Program of the American Association for the Advancement of Science. But, he insists, there is a right way to identify, investigate and adjudicate misconduct cases, and his organization has begun offering a 'nuts and bolts' seminar on the subject to university officials. This year's program, scheduled for June, will also cover the new definition of "scientific misconduct" issued last October by the White House Office of Science and Technology Policy. Under that proposed definition, all federal research agencies will define misconduct as "fabrication, falsification, or plagiarism in proposing, performing, or reviewing research, or in reporting research results."

Back in Arizona, John Marchalonis, head of the Department of Microbiology and Immunology, said that he welcomes efforts to streamline the process. Kay's former boss and her most vocal defender, Marchalonis believes that the Kay case is a perfect example of how easily these cases get out of hand: "I just don't understand how this got blown out of proportion. Science is the real loser."

Tinker Ready, Boston 